\title{
Stories of change: The case of a foundation phase teacher professional development programme
}

\author{
Bruce Brown, Rhodes University.* \\ Di Wilmot, Rhodes University. \\ Margie Paton Ash, Rhodes University.
}

\begin{abstract}
The study reported in this article responds to the need for empirical studies that provide evidence of positive change in education at the micro-level of the classroom an important component of the complex education environment in South Africa. This article describes teachers' and principals' reports of micro-level changes that occurred during a professional development programme for foundation phase teachers at a South African university. An overview of the principles underpinning the programme design and implementation is given, followed by a description of the qualitative research design and grounded theory methodology used to research changes in the practices of teachers participating in the programme. The study provides evidence of changes in the classroom and professional practice of the teachers, aligned with changes in academic practice and children's learning in the classroom. We argue that the programme's strong orientation to practice, its focus on teachers' understanding of children, and the model of teacher professional development that is located in reflexive practice together may have facilitated positive changes in the teachers' practices.
\end{abstract}

Keywords: teacher professional development, foundation phase, elementary school, classroom practice, teacher change, child learning, Northern Cape, grounded theory, South Africa

*Email address: b.brown@ru.ac.za.

South African Journal of Childhood Education | 2015 5(1): 191-209 | ISSN: 2223-7674 |๑ UJ
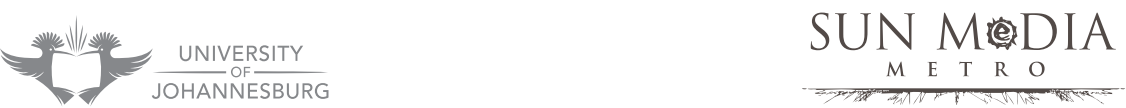


\section{Introduction}

While great strides have been made in South Africa in terms of access to education, the major inefficiency of the system, which is the low quality of teaching and learning, still needs to be addressed. There has been a proliferation of reports confirming that the majority of South African school children are not meeting the national curriculum standards (NEEDU 2013; RSA DBE 2011a, 2013a, b; Spaull 2013). For these children, quality education remains an elusive ideal (RSA DBE2013a). Of significance to this article is the low quality of the system in the early grades, characterised by widespread failure of South African children to reach basic thresholds of literary and numeracy, causing queuing and then dropout in higher grades (ibid).

It is widely accepted that teachers play a critical role in achieving quality education, and that South African teachers' content knowledge and pedagogical content knowledge need strengthening if the quality of learning is to be improved. Furthermore, teachers' weak content knowledge is linked to their weak assessment practices (Taylor \& Taylor 2013). In spite of an upward trend over time in the quality of learning, with considerable improvement noted between 2002 and 2011 (RSA DBE 2013a), a mood of despondency and negativity is still prevalent in South Africa, where the education system is "still in dire straits" (Spaull 2013:58). Poor quality schooling continues to severely limit young people's capacity for training and further education, and has been shown to contribute to high levels of youth unemployment (ibid). The Department of Basic Education (DBE) has implemented a number of policies to address some of the root causes of underperformance, including a new curriculum (RSA DBE 2011b) and Annual National Assessments (ANAs). Similarly, the Department of Higher Education and Training (DHET) has implemented a new qualification framework for teachers, the goal of which is to strengthen teachers' knowledge and pedagogical content knowledge. In parallel with these national responses, universities are providing teacher professional development programmes aimed at improving the quality of practice in schools.

This paper reports on a case study of the professional development of a group of foundation phase teachers. An interesting feature that emerged from this case study is that, while the academic performance of learners in these schools did improve (in some cases, quite considerably), this improvement was embedded within a number of broader (holistic) changes in teachers' classroom and professional practice. In the light of the country's efforts to improve learner performance, it may be important to consider the contribution of such holistic changes in leading to, and maintaining, the improvements in academic performance in these schools.

The teachers in this study were enrolled in a three-year, part-time professional development programme, the Bachelor of Education for Foundation Phase Teaching (BEd(Foundation Phase)), offered by the Centre for Social Development (CSD) in the Education Faculty at Rhodes University, Grahamstown. This programme enabled in-service teachers in the Frances Baard and John Taolo Gaetsewe districts in the Northern Cape to improve their professional teachers' qualifications from a minimum of a three-year teacher's diploma, to a Bachelor of Education degree. 
The overarching goal of the programme was to work for change in the classroom practice of the teachers through the extensive engagement required for the formal BEd (Foundation Phase) qualification, supported by regular visits and support for the teachers in their home districts and schools. The programme consisted of the following elements:

- $\quad$ Twenty days of contact learning at Rhodes University per year, spread over four sessions of one week each during the four South African school holiday periods;

- The completion of approximately ten assignments, incorporating both theory and practice from the course, after the first three contact sessions each year;

- At least one school visit each term by the programme field officer, to provide teacher support and practical assessment; and

- Workshops presented in each district by the field officer to complement the work done during contact sessions at Rhodes University.

During the course of the programme, a number of changes in classroom practice were introduced by the teachers. These included: implementing an expanded repertoire of tools and techniques for teaching literacy, numeracy and life skills; building a more concrete, active and varied learner experience; generating and sourcing a more extensive resource base; changing systems for cleanliness and hygiene in the class; making the physical environment of the classroom more attractive and engaging; and assuming a caring and mothering role with the children. This paper tells the story of these changes, based on the reports of teachers and principals in the schools, and discusses some of the resulting effects on the children, the teachers and their schools.

\section{Research design and methods}

The research was a case study (Yin 2009) focussing on the practice of teachers participating in the particular BEd (Foundation Phase) programme. Data collection and analysis took place in four phases, with the analysis of data collected during each phase informing the design of the research in the following phase.

The first phase included an initial survey questionnaire, which was completed by the programme team and the teachers who had enrolled for the degree. This was followed by an initial interview of the three key academic staff members on the programme. The second phase, which was carried out in the Kimberley and Kuruman districts, consisted of school visits and interviews with principals, teachers on the programme and their colleagues, and a Northern Cape Education Department district official who is familiar with the programme. A number of teachers were observed teaching in their classrooms, and a programme workshop in the Kimberley District was also observed. The third phase took place in Grahamstown near the end of the programme, and included teacher feedback, further interviews of the programme academic staff, and the sourcing of video and assignment data produced during the three years of the programme. The final phase was carried out in the Kimberley and 
Kuruman districts at the start of the year following the completion of the three-year degree programme. It involved classroom visits and interviews with teachers on the programme as well as their principals and colleagues.

An interpretive, grounded theory methodology of data capture and analysis was followed (Birks \& Mills 2011; Charmaz 2006; Glaser \&Strauss 1967; Strauss \& Corbin 1990) to identify and understand possible change processes influenced by the professional development programme. This methodology follows a three-step process in which the researcher begins the research without a hypothesis, describes what is being investigated and unveiled, and then tries to explain why it is so using an inductive process of data clustering. The research design is evolutionary and flexible, as it requires the simultaneous collection and analysis of data. Data are collected and analysed according to a coding system derived from the data in an inductive way.

Initial coding comprised multiple readings of the data to identify recurring incidents related to identifiable concepts. A table of emergent concept descriptors was then developed and passages in the transcriptions related to each concept were identified and coded. This was an inductive process of refining, collapsing, adding and removing concepts, until a collection had been stabilised. The coded passages were then extracted from the transcribed corpus of data to form concept reports. By means of close comparative reading of the extracts, the researchers developed a rich and also integrated interpretation of each concept that had been identified, and noted how it related to others. These interpretations, together with brief extracts from the coded data, form the basis for the discussion presented in this paper.

Reports of the coded data for each concept were prepared and compared for similarities and differences (comparing and contrasting meanings) in order to group the concepts into a hierarchy of categories. A two-level hierarchy was developed as suitable for this data. Four primary categories were identified: 1) physical location of the school; 2) school facilities and resources; 3) sociocultural and socio-economic context; and 4) reported changes in teachers' practice. The interpretive analysis was discussed with the teachers during the final contact session of the course in the light of their interpretation of the changes in their practice. We saw this as a process of 'member checking', which is one of the tools methodologists suggest for strengthening the reliability of research processes (Yin 2009). The teachers agreed with the interpretations, and only a few minor changes were necessary. They also provided further detail on their experience of the process and their motivation and purpose in implementing these changes.

The results of this analysis relating to the last primary category (reported changes in teachers' practices) are presented in this paper as a means of developing insight into reported changes in the practice of teachers enrolled in the programme. The methodology does not allow definitive identification or measurement of actual change. Nor does it allow the drawing of definitive conclusions about the cause of any change identified. We cannot lay claims of causality or correlation between the intervention and its effects, but there are indications of change, which we have captured qualitatively. The practice of teaching is embedded in a complex, open system with multiple 
interacting influences, and the identification of sole, or even primary causes for any reported change, is thus not feasible, but a thorough (or 'thick') description of the change is what we aimed for. On the other hand, interviewing professional colleagues not involved in the programme, including school principals, did allow for some degree of inter-subjectivity when considering reported changes and statements relating to the influence of the programme.

\section{The teaching districts: A context with specific sociocultural challenges}

Kimberley and Kuruman are located in the Frances Baard and John Taolo Gaetsewe districts of the Northern Cape, the largest (covering 30\% of the country) and most sparsely populated province in South Africa. The total population is 1.14 million $(2.2 \%$ of the total national population). The Northern Cape economy, which is largely dependent on mining and agriculture, is the lowest contributor (2.3\%) to the national economy (Tibane \& Vermeulen 2014:9).

The National Development Agency (NDA n.d.) identified several challenges affecting people directly as a result of poverty. High unemployment (27.8\% in 2010), exacerbated by diminishing resources in the alluvial diamond fields, has resulted in an increase in the number of people dependent on state grants. There are also health challenges, including malnutrition and foetal-alcohol syndrome (FAS), tuberculosis, chronic diseases such as hypertension, and HIV/AIDS. Education is another challenge for people living in the Northern Cape, with $26 \%$ of the population aged fifteen years and above having "no education or highest level of education less than grade 7" the third highest percentage of all nine provinces in South Africa (SSA 2011:43). One indicator of the ongoing challenge of quality foundation phase education in the Northern Cape is the low level of learner performance of Northern Cape children in the 2013 Annual National Assessment (ANA), summarized in Table 1.

Table 1: 2013 ANA results for Grade 3 in the Frances Baard and John Taolo Gaetsewe districts compared to the provincial and national average (South Africa. DBE, 2013: 74)

\begin{tabular}{|l|l|l|l|l|}
\hline \multicolumn{1}{|c|}{ District } & \multicolumn{2}{c|}{ Mathematics (Average \%) } & \multicolumn{2}{c|}{ Home language (Average \%) } \\
\hline & 2012 & 2013 & 2012 & 2013 \\
\hline $\begin{array}{l}\text { Frances Baard } \\
\text { (Kimberley) }\end{array}$ & 39.3 & 53.8 & 49.1 & 48.7 \\
\hline $\begin{array}{l}\text { John Taolo } \\
\text { Gaetsewe } \\
\text { (Kuruman) }\end{array}$ & 31.0 & 41.9 & 44.0 & 37.7 \\
\hline Northern Cape & 37.9 & 50.5 & 49.4 & 46.2 \\
\hline National & 41.2 & 53.1 & 52 & 50.8 \\
\hline
\end{tabular}

(Source: RSA DBE 2013:74) 
The Centre for Social Development (CSD) in the Education Faculty at Rhodes University was successful in a tender bid for a teacher professional development programme in the foundation phase issued by the Northern Cape Education Department in response to the challenges facing schooling in the province.

\section{The professional development programme}

The academic component of the professional development programme was a BEd (Foundation Phase) degree qualification consisting of a core curriculum and additional components specifically designed for teachers working in the foundation phase at schools in the Northern Cape. The initial professional education of the teachers was such that they were granted recognition for 240 credits of the 480 -credit qualification, and they were enrolled for the final 240 credits of the BEd programme, spread over three years of part-time study.

The academic component of the programme was supplemented by workshops and school-based support for the teachers, provided by a fulltime programme field officer, as well as annual school visits by the programme's university-based academic staff.

The following principles informed the programme's design, curriculum and pedagogy:

- A specialised programme with content, theory and practice oriented towards what teachers need to think about in Grades $\mathrm{R}$ to 3, and what they need to understand about children in the foundation phase of schooling.

- Scaffolding and progression are critical, both in the programme and in foundation phase teaching. Programme modules were structured in such a way that each lecture built upon knowledge and content learned in previous lectures. This principle was extended to the teachers' classroom practice, with teachers expected to do more challenging work with children in Grade 2 and 3, because all too often children in these grades are insufficiently challenged by their teachers.

- In order to be in line with the current schooling context, the orientation of content subjects such as language, mathematics and life skills was aligned to the national curriculum (RSA DBE 2011b). This was guided by compact and comprehensive single-page resources for each focussed content area - organised and collated from the Curriculum and Assessment Statement (CAPS) documents for Grades R to 3 - in the corresponding subjects (RSA DBE 2011b). For example, the resource for language in Grade $R$ included speaking, phonics, reading, viewing and handwriting, all on one page for easy reference.

- The teacher professional development model combined reflection on practice where teachers were expected to routinely review their lessons to consider what worked and what did not - with reflexive practice, where teachers were expected to routinely adapt lessons to make them more effective (Hargreaves \& Fullan 2012). In keeping with this, programme modules and courses were continuously evaluated, adapted and refined to address identified shortcomings. For example, in response to 
poor second-year examination results in reading instruction and development, and phonics, these areas were made focal points in the third-year course.

- The pedagogical model aimed to provide teachers with opportunities to experience theory in practice in a concrete and practical way. An activity would be discussed in response to carefully selected questions, and the abstract conceptualisation and methodology in practice would then be developed from this discussion. Students would then be asked to practice it themselves.

- A commitment to academic rigour, with theory, such as the theory of emergent literacy, being used as a vehicle for discussion and debate about ideas and practices that are important to foundation phase teaching, and to mediating theory so as to make it accessible to the teachers' thinking and practice.

- Due to the limited contact time of the programme, coherence of the different aspects of the programme and relevance to practical classroom implementation were important organising principles.

\section{Analysis and discussion: How did practice change?}

The data from various sources (questionnaire responses, interviews with teachers on the programme, and interviews with professional colleagues, including principals) were analysed in relation to reported changes in practice at the micro-level of the classroom. In addition, possible (perceived) influences of the programme on implementing these changes and on the personal and professional development of the teachers were considered during the analysis.

This analysis relates to the primary analytical category of reported changes in teachers' practices. The secondary categories and coded concepts that were grouped together to form this category are given in the following table:

Table 2: Secondary categories and coded concepts for reported changes in teachers' practices

\begin{tabular}{|l|l|}
\hline \multicolumn{1}{|c|}{ Secondary Category } & \multicolumn{1}{c|}{ Coded Concept } \\
\hline Aims and goals as teachers & Aims and goals as teachers \\
\hline \multirow{4}{*}{$\begin{array}{l}\text { Systems to manage the physical environmen } \\
\text { put in place since joining the programme }\end{array}$} & Water systems \\
\cline { 2 - 2 } & Food preparation and consumption \\
\cline { 2 - 2 } Systems to manage the children, put in place & Plants \\
\cline { 2 - 2 } \begin{tabular}{l}
\multirow{2}{*}{ since joining the programme } \\
\cline { 2 - 2 }
\end{tabular} & Use of the toilets \\
\cline { 2 - 2 } & Discipline \\
\cline { 2 - 2 } & Duty rosters \\
\cline { 2 - 2 } & Rewards systems \\
\hline
\end{tabular}




\begin{tabular}{|c|c|}
\hline Secondary Category & Coded Concept \\
\hline \multirow{11}{*}{ Classroom tools and resources } & Quality resources (lack or availability) \\
\hline & Workbooks \\
\hline & Reading corners \\
\hline & Books \\
\hline & Big books \\
\hline & Group guided readers \\
\hline & Graded readers \\
\hline & Print rich classrooms \\
\hline & Theme tables \\
\hline & Weather charts \\
\hline & Birthday calendars \\
\hline \multirow{3}{*}{ Lesson preparation and presentation } & Time spend preparing \\
\hline & Planning to a theme \\
\hline & Introducing English in grade 3 \\
\hline \multirow{6}{*}{$\begin{array}{l}\text { Understanding, appropriating and } \\
\text { implementing theoretical aspects of the course }\end{array}$} & Language: group guided reading \\
\hline & Mental mathematics \\
\hline & Physical movement \\
\hline & Teaching values \\
\hline & Differentiated instruction \\
\hline & Importance of play \\
\hline \multirow{4}{*}{ Teacher professionalism } & Commitment to work \\
\hline & Absenteeism \\
\hline & Sharing new knowledge \\
\hline & Influencing colleagues \\
\hline
\end{tabular}

Through a detailed reading and comparison of the concept reports, a number of themes relating to particular changes reported in the data were identified during further analysis, using core concepts to anchor the themes. These themes were used to compose the 'stories of change' in the remainder of this paper. These stories will include extracts from the coded data in order to indicate the particular data that the narrative analysis draws on - a 'thick' description, in a form that is reminiscent of "ethnographic casebooks", (Henning 2000) of the teachers and their colleagues - and to provide a rich account appropriate to the data. It should be noted that the use of 'story' in this discussion is aimed at revealing the 'human face' of the data, and should not be seen as indicating the use of a narrative methodology.

\section{Stories of teacher change: Moving closer to the core of the profession}

Teachers reported that they had worked to implement a number of changes in their practice over the course of the programme. In the process, they had developed a growing interest in their teaching and found it more rewarding. A number of teachers stated that they had lost interest in teaching before attending the programme, with two saying that they had thought of "quitting teaching". Nine teachers said that their commitment to teaching foundation phase children had grown over the course of 
the programme, and that they were now finding great satisfaction in their expanding role of "growing and mothering these young children". Twelve teachers commented that their self-confidence had grown as a result of participating in the course. One teacher wrote: " $[T]$ his course has affected my personality tremendously, as I am know [sic] a caring, loving and kind mother of the learners, community, colleagues and my family."According to another, the programme had changed her teaching and her understanding of what was expected from her:

I now know how young minds learn and what I must do to discipline my children so that teaching and learning can be effective. I didn't have classroom rules, group rules, etc. I didn't follow what I must do in class on a daily basis as expected. The course has opened my eyes.

These accounts were supported and expanded by what the principals and colleagues of the teachers had to say. One principal noted the teachers' growing commitment to the learners, as evidenced by their interaction with the children in their class, and the extended time they spent preparing and maintaining their classrooms and resources for their teaching.

They have grown a lot. They have become more positive about their teaching environment and you can actually see the improvement in their classes. In fact, they lift the standard for what a classroom should look like, also their attitude towards teaching; it is absolutely amazing how positive they are about the programme. It is not just another course; they are benefiting from it, and they are eager to implement what they have learnt [...] their standard of service delivery has improved, [as well as] their attitude and commitment towards teaching.

\section{Changes in learners: Children engaging with the joys of learning}

Substantive change was evident in the learners and learning in the classes of these teachers. All the principals interviewed reported improved engagement by children in classroom learning activities. The fieldworker also observed that learners taught by these teachers did not rush home at the end of the day, but appeared happy to stay with their teachers in their classes or play outside with their peers, coming in to visit their teachers every now and then.

As an indication of changes in children's learning, three principals reported improved ANA results for Grade 3 literacy. One principal reported that, prior to the two teachers at this school attending the course, the school had achieved ANA results below $50 \%$ for foundation phase literacy; since they had been on the course, the corresponding results had reached $60 \%$. At another school, where three teachers followed the course (one in each grade), it was reported that the ANA results for foundation phase literacy had improved from $30 \%$ to $50 \%$ in the third and final year of the programme. In the third school, where the head of department in charge of the foundation phase was on the programme, the principal reported that they had to double-check the results to make sure that they were correct, as the foundation phase had done exceptionally well.

A number of other changes that appeared to have contributed to these teacher and learner changes were reported. 


\section{Changes in everyday practice and care in the classroom}

\section{Health and hygiene}

It was reported by teachers and their colleagues that they had developed a stronger awareness of health and hygiene during the three years of the programme, particularly, the importance of good hygiene for a positive school experience. When discussing the organisation of the school feeding scheme, a teacher explained: "I also make them aware that these things are very dirty and there are a lot of germs on the tables, so it is not good to take those slices and put them on the tables."This increased awareness had an unanticipated positive effect on the teachers' and their colleagues' routines and practice.

Every teacher, except one, had developed a closed water system to ensure that children had access to safe and clean drinking water and water for washing their hands. They had introduced a number of different clean water systems. Some used individual bottles for drinking water, others used individual cups and others sterilised the few cups they had after being used by each child. One teacher explained that since attending the course she had realised that "it is not hygienic to wash in one basin, so we asked the principal to buy us those bottles. So they wash under running water with soap and they rinse [sic] their hands with a towel." A closed container with a tap was the most common way of providing clean water in all the schools. The presence of replicated water storage systems outside other classrooms, notably those next door, suggests that the teachers had an influence on their colleagues.

Self-reports and observations indicated an increased awareness of conserving and using water for greening and beautification of the school environment, which contributed to changes in teachers' practices. At five of the schools, the teachers had plants growing in pots or outside their classrooms, with the wastewater from handwashing being used to water these. A teacher described how she had been encouraged by the field officer to plant flowers in front of her classroom.

The pastoral role of the teachers, that is, their responsibility for the general wellbeing of their learners, broadened from one of mothering individual children to embracing a more social role. This was evident in how the teachers developed new systems for implementing the free daily meal provided for the majority of the children through the National School Nutrition Programme (NSNP). In the Northern Cape, the NSNP provides an average of 186167 learners in quintile 1 to 3 schools with a nutritious free daily meal (RSA DBE2013c:42). The meal (rice and tinned fish, bread with juice and a fruit, or cabbage and pap or samp) is normally served between 10 hoo and 10 h30. Changes had been made to the way the class was set up for the meal and how it was served and consumed.

Initially, the food was brought to the classrooms in buckets that had not been carefully cleaned, and the children would mostly eat outside using their hands. All teachers on the course changed this practice to a more hygienic one, where food was served from clean buckets onto clean plates. Meals were now eaten in the classroom 
on individual plates, on desks covered with mats or cloths. In addition, all children washed their hands before eating. One teacher explained the change as follows:

We used to just give them bread because there are three slices and they just normally take it out of the plate and eat. So the school realised that it is not necessary for us to use the plates. So, after joining this programme I realised that this is more than a health hazard so I decided to challenge the management and ask them to reverse the decision that we made. And at least they listened to me, so my children, on a Friday, they are served with plates. And I also make them aware that these things are very dirty and there are a lot of germs on the tables so it is not good to take those slices and put them on the tables.

Most teachers made the meal a social occasion and used the time for teaching life skills related to eating. One teacher said:

We never had flowers, we never had table cloths, and then [the field officer] said "you cannot treat them [the children] like that. Because you are having a table cloth on the table, they also need that." We are not just dishing out food, we explain why they are eating this kind of food.

Another teacher mentioned that, at meal times, she would walk around the class and teach good table manners: "I teach them that it is rude to speak while they eat with their mouths open and things like that. "In two of the classes observed, the teacher and children discussed the food and healthy eating.

\section{The classroom environment: Inviting and print-rich}

It was notable that the classrooms of the teachers on the course looked inviting and child-friendly. The classrooms of most other teachers were in a poor state of repair and had little of interest on the walls, in stark contrast to the clean and attractive classrooms of the teachers on the course, which had brightly coloured walls and colourful containers to hold workbooks and other resources used for teaching. One teacher reported that she had changed the more traditional layout (desks in straight rows) of her classroom after a programme activity that required drawing a classroom layout. Based on these ideas, she had changed her classroom layout to one with desks arranged in a way that facilitated children being in groups. She had painted the room in bright colours, and fitted bright curtains to shield the children from the hot sun. She also introduced neatly labelled, colourful containers for storing resources.

The programme helped to increase the teachers' awareness of cleanliness. We observed how the teachers ensured that the children worked at desks or tables that were clean. One teacher explained:

Our tables were so dirty and, you know what, we were not even aware of our tables at the time, we just took it as there was nothing that you can do, they are like that. But since the [field officer] has come into our classrooms she has showed us. We also found out that these tables are dirty so we decided to put on table cloths. The chairs needed to be washed.

She solved the problem of dirty chairs by having the children scrub their desks with soap and brushes every Friday. Another teacher showed us the flowers (pot plants) she put in her classroom to make it more attractive. She said: "I never realised that I can keep flowers in my class. Every time when we close the school I just take them back 
home." A deputy head of one school commended the eight teachers from her school for keeping their classes clean: "They [the teachers] come to us although we're running short of cleaning materials, but they improvise and say "I will bring along washing powder and come and clean up my classroom [...]."

The programme developed the teachers' awareness of the importance of creating print-rich classrooms by making and hanging posters on the walls and labelling everything in the classroom. One teacher described how proud she felt now that she could type her own labels: a skill she had learnt since joining the course. Another teacher said: "I have made my hand prints and [I will] write under it, left and right. I make sure that everything that we do with them is [also] in writing. I make sure that I write them down, the labels. "She described how she wrote phrases on the labels; for example, "'Let's learn to read and write' and 'we like to read and write'." She used the labels to promote incidental reading and would read them aloud to her Grade 1's. Another teacher recognised the importance of building vocabulary and had made a word wall showing all the words that the children were learning. This was kept up to date with the theme that was being taught and the books that were being read. Weather charts and birthday calendars were common features in the classrooms of the teachers on the course. The teachers were all using themes and theme tables as teaching tools in their classrooms.

Many of the teachers indicated that they did not have access to quality resources and often resorted to making their own resources or asked for donations of equipment or resources. A few teachers had bought resources using their own money: one teacher downloaded pictures off the Internet for her classroom and paid for them to be printed and laminated. Another had found empty boxes in the photocopy room and had covered them with brightly coloured Christmas wrapping paper for resource storage.

\section{Classroom behaviour: Managing the social space}

In every class observed, the teacher had a firm, yet quiet and gentle control of her class. This may have been one reason why the children regarded them as mothers in the classrooms. The teachers acknowledged that the way they managed their classrooms had changed since being on the course. They spoke to the children with quiet voices, and a number of teachers explained why:

If you raise your voice to the children, they will also raise their voice. If you scream they will also [scream].I learnt from Rhodes that you must not raise your voice when you talk to them. If you raise your voice they will also raise their voice.

When discussing discipline, one teacher said:

Even if the child had done something wrong, we must not be so angry. We must try and talk to [them] and sometimes their peers, they must try to correct [the child]. I must give them the opportunity, so the peers can correct each other. 
Colleagues appeared to have noticed the change. One teacher described how a colleague had said in a staff meeting:

I have realised now that maybe the children are so violent because they [the staff] keep on shouting, shouting, but when Mrs X (she is referring to me) comes into the class they become quiet.

Another teacher explained that the change was deeper than just how she talked, saying that she had "really changed. I love my children". She added that, at the programme's contact sessions, the lecturers had taught them how they should treat their learners. Changes in how all the teachers on the programme interacted with the children they taught were evident from the happy, disciplined classes we observed. Principals noticed this, with one describing how there had been "a quiet improvement in the discipline of the learners", and another commenting that the discipline of the children in the classrooms of the teachers on the course was "excellent". It was also encouraging to note how the teachers were modelling the respectful behaviour they expected from the children.

The teachers had developed systems for managing their classes by distributing duties amongst the children, enabling greater participation and acceptance of responsibility. Duty rosters were now displayed in all classrooms, helping to organise the children so that, according to one teacher, "they know who does this and who does that, because they all want to work at once and it is not possible". Duties included looking after the weather chart, collecting and handing out books, watering the plants, cleaning tables, and laying out the cloths for the meal.

Rules and routine had become important, and were prominently displayed in all classrooms. In many of the lessons observed, these rules were constantly referred to and reinforced. A teacher explained how she had changed:

In the past we didn't have rules. We have [sic] rules but we didn't implement them. We just write [sic] the daily routine, but sometimes they can go [sic] for a week not using them. But I have learnt that those are the things that hurt the child.

She had even tried to persuade the parents to "make the routines at home, tell the child this is what you have to do". Rules differed substantially between teachers, with each having decided on rules best suited to their context.

Some teachers explained that they had learned to teach the learners in smaller groups according to their abilities. In some of the classes observed, this strategy appeared to be working well. Teachers had learned, for instance, how to split the class into groups, with one group being occupied with an exercise at their desks while the teacher did a reading or a mathematics exercise or lesson with a smaller group on the carpet. Furthermore, the switch from one subject to the next was smooth and effortless, with certain children being allocated duties regarding the handing out and gathering of workbooks and other resources needed for the lesson.

It seems that the transformation of classrooms into organised and attractive learning spaces, together with the greater mothering role played by the teachers, allowed the children to feel comfortable at school. It was observed that the children 
did not rush home at the end of the school day and seemed happy to stay and play at school. In some classes, an improvement in children's school attendance was reported. A teacher on the course mentioned that her colleagues had commented on how much she had changed and how the course had "built her so much", and how the children in her class were always at school: "they don't dodge, they come to school regularly."

\section{Core activity: Reading and books}

During the three years of the programme, every teacher created a reading corner, which they used as a tool for teaching. Mostly it consisted of a rug or carpet, shelves for books, some comfortable cushions, and/or some chairs. Two teachers allowed the children to read books once they had finished their work, and in one teacher's class, children were observed relaxing on the cushions and reading books after school had ended.

A lack of books was identified as a problem by teachers, one of whom said:

If I could just have enough books! Sometimes I photocopy. If you don't have enough books you struggle and you just use books inside the classroom. There is a need for children to take books home so that they can go and read [... ] It is a problem; it is a big problem for us.

As part of the programme, the teachers had written to Biblionef to ask for donations of books for their classrooms. These books were delivered and distributed among the classes. Although there were not many books, this was a start to building class collections. The teachers were also made aware of the need for big books to teach reading, and these were present in most classrooms, albeit not in large numbers. After a reading lesson using a big book, one teacher mentioned that she and a colleague had gone shopping to buy books, and she had explained to the teacher accompanying her why big books were good for teaching reading. The teachers were also taught to use graded readers for guided reading. We observed that the grading of readers was at different stages of implementation; some teachers had done this and others had not.

A big change in all the classes was the introduction of guided reading for language instruction. One teacher commented on the "excellent way [the lecturer] taught us to do group guided reading", explaining that one group would sit on the carpet doing silent reading or paired reading while she dealt with the other group. Another teacher said that since being exposed to group guided reading in the programme, she had implemented it in her class and her "learners have benefited a lot". Yet another teacher stated that her class had struggled with reading, but that since she had introduced techniques such as group guided reading, they were starting to read. One teacher explained how they had been given group guided readers by the learning area manager, but they hadn't understood what to do with them until they joined the programme. Another teacher said that she only understood how to teach reading after reading strategies had been explained to them on the programme. 


\section{Numeracy and mathematics}

Many of the teachers were observed teaching mental mathematics, and this was new to their teaching. One teacher reported that after attending the first session of the year, she had returned to school "well-equipped with mental maths." She added that, previously, "every time the children had to do maths, they write, write, write. But mental maths is something they have to do orally. "Another development was that the teachers had learned a number of practical ways to involve the children more and get them to think for themselves. Asking the children to explain their answers was something that one teacher had never done before, and she stated that the children now knew that they would have to do this, and hence thought more about their answers. Another teacher was observed trying to extract from the learners how they had reached their answers to some addition problems in a mathematics lesson. A third explained that doing it this way helped other children who were observing to understand how the answer were arrived at.

The teachers had sourced different mathematics resources for their classes, particularly for counting: some were bought and some were handmade. One teacher had used pasta of different sizes, shapes and colours. Another had covered tins with numbers and had also made dominos. Yet another used acorns she had gathered in Grahamstown for counting exercises in her class back home. She had also collected bottle tops for counting. A few of the teachers had managed to buy posters displaying numbers. One of the teachers said that she was now aware that she needed to have the 100 chart (numbers up to 100) on the wall. It was revealing that all these new homemade counters and resources for mathematics had been introduced since the teachers joined the programme. One teacher explained:

I never realised that I could use egg boxes to teach fractions and I learnt that from this course. So I never used egg boxes before, I am honest. Last year I made myself a theme table for fractions for the Grade 3's where, because it was easy to do it with egg boxes, you take 18 and work in 3's: 9 is half. I made it with egg boxes. It was so interesting. I loved it so. I never used the egg boxes before.

The importance of mathematical language had also been brought home to the teachers. One teacher explained that this had resulted in a change in the language she used when teaching mathematics:

[D]on't say 'give the answer of'; say 'give the product of' or 'what is the sum of?', so they have to keep a dictionary where they will write the term and the explanation of the mathematical [term] in everyday English.

After learning this, the teacher concerned had called a staff meeting, given a report, and asked the school to buy index books. A number of the teachers were using these in their classes to teach mathematical language. The teachers were actively pursuing the current debate about whether children should be expected to use their home language or English for referring to numbers. Most of the teachers used English, but one teacher said that it was important to teach the children the numbers in Setswana, as the ANAs required them to be able to read numbers in their home language. Another disagreed, pointing out that she always took the background of the children into consideration 
when planning her lessons. According to this teacher, the parents did not use Setswana words for numbers. She explained:

When the parents send them to the shop they don't speak Setswana. They don't use Setswana words; they say they give them Twenty Rand. They say one, two, and three.

\section{Physical activity and play: Learning in the childhood years}

The introduction of physical movement was another departure for the teachers on the course. One teacher could not say why movement was important, but she described how much the children enjoyed the lessons:"we play games, we play ball, we use bean bags, we run, we jump; all those sorts of things [...] they enjoy." Most of the teachers justified the importance of movement for physical development and other educational purposes. A teacher explained that she now understood that physical education was related to healthy minds: "[...] balancing so that they will be able to focus. Laterality, so that they know left and right, and this would help them when they write." She did a hopping exercise with the class to help her determine which side was dominant in each child, as this was important for teaching writing. Another teacher said that if a child was struggling to write, she would take the child outside, because she knew that "running [and] skipping will help them". She added that skipping, running and "playing wheelbarrows" helped strengthen their muscles, and how by watching how they moved, she could work out which was the child's dominant side.

There was a new emphasis on play since the teachers had been on the course. Many teachers were observed using songs and movement to introduce new exercises. One of the teachers said that she had learned about play at Rhodes University, and that she had not known that playing could be constructive or that it could be planned. She never realised that when children played, they learned things more easily, and had come to this conclusion when she taught the children to recite a rhyme whilst skipping. She also mentioned that she would often sing when she gave instructions to the children, and they tended to listen to the song and then realise that the song had a message. One of the teachers explained that using movement in combination with singing was good for the children when they had been sitting in the classroom for a long time and were bored and tired. Her learners were observed singing two different songs; in one, they pointed to different parts of their body and then to different directions in the classroom, such as front, back, up and down. Another teacher said that she had started bringing her laptop to school so that she could play music to soothe the children when they were eating or had just come back from physical education.

\section{Teacher professionalism: dignity, skill and motivation}

A few teachers indicated that they had learned to plan and manage their time better as a result of being on the course. It was clear that many teachers on the course spent a lot of time preparing their classrooms and their resources for their lessons. Some of them stayed at school in the afternoons and even came to the school over weekends to prepare their classrooms. Several principals commented on this and 
were complimentary about this change in the way the teachers approached their work. A common theme was the increased commitment shown by the teachers on the course. One principal, who had two teachers on the course, felt that these teachers were "going the extra mile in all the things that they are doing."Since being on the programme they had come to school on Saturdays to prepare for the week, and often asked him not to lock the school in the afternoons, as they wanted to stay and prepare their classes for the next day. Another principal commented that the two teachers on the course "are working hard nowadays, and [...] since being on the course they left the school at 5 or 6 o'clock." Yet another principal, who had three teachers on the course, remarked, "[T] heir professionalism is outstanding. The way they approach their work now is different to what it was before. They are on time and they are prepared for lessons."

A decrease in absenteeism by the teachers on the course was also noticed by two of the principals. One principal noted that her teacher's attendance as well as her performance in the classroom had improved, and whereas prior to the course, the teacher was "a person who liked to be absent, to be out of school, now she is always at school."The principal also commented on how the course had helped change this teacher's attitude from being " $a$ little bit negative with everything. She has spent her whole teaching career here and she was a bit negative, but now she is positive about everything. It has changed her."

\section{Conclusion: An academic programme becomes an integrated development agent of change}

This article has provided some insight into reported changes in teachers' practice related to a teacher professional development programme emphasising reflexive practice and including school visits and classroom-based support. The BEd (Foundation Phase) programme appears to have contributed to positive changes in practice at the classroom level. Teachers' reports indicate that the programme helped them to reflect on their practice and develop professionally as well as personally. They showed an awareness of the ways in which they had changed, and colleagues had also noted changes in their practice. Teachers appeared to become more resourceful and creative in their teaching, as evidenced in the data and their reports of many different changes in practice they implemented in their classrooms during the course of their studies. Changes in the way that they taught literacy and numeracy yielded learning gains for the children, as evidenced by the reported improvements in their learners' ANA results.

The programme's inclusion of knowledge about the physical and social development of children appeared to help the teachers develop a deeper understanding of the children they teach. We would argue that this understanding of child development may have been instrumental in deepening their practice. This balance of deepening knowledge and practice was evidenced by the strong orientation towards practice in the programme. It involved working with the teachers to develop, resource and implement appropriate systems of practice to embody their developing knowledge of children in 
their teaching. The resulting interaction between developing knowledge and developing practice formed a closed-loop system that supported their efforts to improve.

Underlying the teachers' development in terms of teaching academic content was a second system relating to children, their classrooms and the profession of teaching, which, we argue, contributed to the change in the teachers' orientation and practice. The teachers' awareness of their pastoral role of caring for and 'mothering' their learners deepened; they learned to appreciate the importance of creating an attractive, stimulating, text-rich, child-friendly, healthy, pedagogical space conducive to learning; and they developed a professional commitment to working for the growth and development of the child. This growing awareness was evident in the many reported changes in practice relating to health, the classroom, and their learner and classroom management.

An important feature of both of these systems of change in the teachers' lives was that changes could be practically implemented, and that the results of many of these practices were clearly seen as positive; for example, in the attractiveness of their teaching environments and the improved efficiency of management systems, as well as in the responses of children, other teachers and even principals. This positive reaction balanced and justified the hard work of completing the programme and enacting the changes in their classrooms, and resulted in the teachers reflecting positively on the course and the manner in which it had affected their practice.

\section{References}

Birks, M. \& Mills, J. 2011. Grounded theory: A practical approach. London: Sage.

Charmaz, K. 2006. Constructing grounded theory: A practical guide through qualitative analysis. London: Sage.

Glaser, B.G. \& Strauss, A. 1967. The discovery of grounded theory: Strategies for qualitative research. London: Weidenfeld and Nicolson.

Hargreaves, A. \& Fullan, M. 2012. Professional capital: Transforming teaching in every school. New York: Teachers College Press.

Henning, E. 2000. Walking with 'barefoot' teachers: the fashioning of an ethnographic casebook. Teaching and Teacher Education, 16(1):1-16.

NDA (National Development Agency). n.d. Northern Cape. Retrieved from http://www. nda.org.za/?option=3\&id=1\&com_id =253\&parent_id=158\&com_task=1 (accessed 23 July 2014).

NEEDU (National Education Evaluation and Development Unit). 2013. National Report 2012. Pretoria: Department of Basic Education.

RSA DBE (Republic of South Africa. Department of Basic Education). 2011a. Integrated strategic planning framework for teacher education and development in South Africa 2011-2025 (Technical Report). Pretoria: Department of Basic Education. 
RSA DBE (Republic of South Africa. Department of Basic Education). 2011b. National Curriculum Statement (NCS) Curriculum and Assessment Policy Statement. Pretoria: Department of Basic Education.

RSA DBE (Republic of South Africa. Department of Basic Education). 2012. Annual National Assessment - Report on the Annual National Assessments 2012: Grades 1 to 6 and 9. Pretoria: Department of Basic Education.

RSA DBE (Republic of South Africa. Department of Basic Education). 2013a. The internal efficiency of the school system. Pretoria: Department of Basic Education.

RSA DBE (Republic of South Africa. Department of Basic Education). 2013b. Education for All (EFA) 2013 Country Progress report: South Africa. Version 10 October 2013. Pretoria: Department of Basic Education.

RSA DBE (Republic of South Africa. Department of Basic Education). 2013c. National School Nutrition Programme Annual Report 2012/2013. Pretoria: Department of Basic Education.

RSA DEDEAT (Republic of South Africa. Department of Economic Development, Environmental Affairs and Tourism). 2013. The Socio-Economic Review and Outlook for the Eastern Cape. Bhisho: Department of Economic Development, Environmental Affairs and Tourism.

Spaull, N. 2013. South Africa's Education Crisis: The quality of education in South Africa, 1994-2011. Johannesburg: Centre for Development and Enterprise.

SSA (Statistics South Africa). Census 2011. Pretoria: Statistics South Africa.

Stauss, A. \& Corbin, J. 1990. Basics of qualitative research: Grounded theory procedures and techniques. London: Sage.

Taylor, N. \& Taylor, S. 2013. Teacher knowledge and professional habitus. In: N. Taylor, S. van der Berg \& T. Mabogoane (Eds). Creating Effective Schools. Cape Town: Pearson.

Tibane, E. \& Vermeulen, A. (Eds). 2014. South Africa Yearbook 2013/14. 21 $1^{\text {st }}$ Edition. Pretoria: Government Communications (GCIS).

Yin, R.K. 2009. Case study research: Design and methods. $4^{\text {th }}$ Edition. Los Angeles, CA: Sage. 